XXV. New Species of Coleoptera from Chontales, Nicaragua. By H. W. Bates, F.Z.S., Pres. Ent. Soc.

DURING the past few months, three or four small collections of Coleoptera have been received from the province of Chontales in Nicaragua, the product of the researches of Mr. T. Belt, and Mr. E. Janson, junr. These collections contained so large a proportion of new and handsome species of tropical American types, that they have attracted much attention among Coleopterists, and no apology is needed for the present attempt to make some of them better known. Further collections may be expected, and any general account of the Coleopterous Fauna must be deferred for the present.

\title{
LONGICORNIA.
}

\section{Mallaspis paradoxa.}

Elongata, convexa, postice attenuata, subtiliter punctulata, fusco-ænea, elytris postice castaneis; capite angusto, longissimo; thorace spinâ laterali pone medium fortissimâ, antice valde attenuato, margine lævi carinâque marginali obsoletâ ; antennis corpore tertiâ parte brevioribus, lævibus, violaceis, apices versus gradatim rufescentibus, articulis 3-6 compressis, paululum dilatatis, cæteris subcompressis, angulis totis rotundatis; pedibus violaceis, lævibus; corpore subtus vix punctulato, lateribus aureopubescenti, prosterno transversim rugato.

Long. 1 un. 9 lin. -2 un. ( $q$ ?).

This singular species differs from all its allies by the absence of a lateral carina to the prothorax, a trace of which only remains near the anterior margin. In conjunction with this, the lateral spine stands out very prominently and is unusually stout and long, the thorax is rapidly narrowed from the spine to the front margin, and the disc has only a few fine scattered punctures. The brassyfuscous colour gradually changes into castaneous, from near the base to the tip of the elytra. In colour and punctuation, as well as in the length of the head, the species approaches the Mexican M. longiceps of White, but this has the usual crenate prothoracic carina, and the antennal joints are linear, with distinct angles. In $M$.

TRANS. ENT. SOC. 1869.-PART v. (DECEMBER.) 
paradoxa the joints have rounded angles, as in $M$. scutellaris. I am uncertain about the sex of my two examples, but from the shortness and smoothness of the antennæ, \&c., I judge them to be females.

\section{Ophistomis picticornis.}

Flavo-testacea, capite utrinque vitta nigra usque ad marginem posticum thoracis continua; elytris (ad humeros latis) utrinque maculis lateralibus tribus, quartaque discoidali prope scutellum, et marginibus anguste nigris, apicem versus litura indistincta fusca; antennis nigris, articulis 7-9 albis; prosterno utrinque vitta, ventroque annulis quatuor, nigris; pedibus flavis, femoribus et tibiis apice, tarsis totis nigris.

Long. 8-9 lin. ( $\left.\sigma^{\pi}\right)$.

Two examples.

\section{Agaone monostigma.}

A. molorchoidi affinis ; angustata, rufo-testacea ; thorace cylindrico, confertim grosse punctato, vitta mediana postice abbreviata nigra; elytris abdomine multo brevioribus, truncatis, vix nitidis, punctatis, punctis lateralibus grossioribus, ibique vitta marginali nigra; antennis dimidium corporis superantibus, apice incrassatis, nigris, sparsim ciliatis; femoribus apice supra, tibiis et tarsis (partim) nigris, femoribus posticis apice bene distincte nigrocinctis.

$$
\text { Long. } 3 \frac{1}{4} \text { lin. ( } q \text { ). }
$$

One example.

\section{Crioprosopus rutilans.}

Angustatus, supra lævissimus, capite thorace et scutello nigris, ely tris viridi-æneis politissimis, nitore cæruleo certo situ splendentibus; metasterno et ventre obscure rufis, nigro variis, lævibus ; pedibus nigris, femoribus annulo læte rufo; thorace transverso, supra subæquali, sparsim punctulato, utrinque tuberculo grosso mediano alteroque obtusiori anteriori; antennis corpore paulo longioribus $(q)$, articulis $4-11$ albo-sericeis ; prosterno convexo, apice rotundato; metasterno triangulari, producto.

Long. 1 un. 2 lin. ( $q$ ). 
One example. A second (male) specimen was also sent by Mr. Belt, but I do not know into whose collection it passed.

\section{Coelarthron quadrinotatum.}

C. bilineato formâ simillimum; nigerrimum, politum, sparse griseo-setosum; thorace vittis duabus antice abbreviatis albo-sericeis; elytris pone medium fascia ad suturam interrupta, et litura prope basin e lineis tribus formata (duabus longitudinalibus unaque transversali), testaceoalbis; antennis ( $\delta$ et $q$ ) articulis $3-6$ triquetris, apice valde dilatatis.

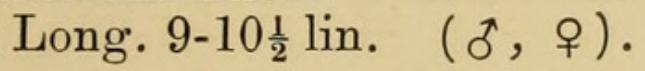

\section{Chalastinus rubrocinctus.}

Niger, opacus, elytris in medio fascia communi coccinea; an tennis ơ corpore duplo longioribus, articulo primo gradatim fortiter clavato, $3^{\circ}$ apice intus dilatato et nigrohirsuto, cæteris apice nodosis, medio pallide rufo-griseis, ultimo præcedente multo breviori, obtuso; mesosterno simplici ; tarsis articulis basalibus griseis.

Long. 7-9 lin. $\left(\delta^{*}, q\right)$.

The narrow crown with elevated approximate antenniferous tubercles, the nodulous tips of the antennal joints, and the slightly dilated front tarsi of the $\delta$, bring this handsome species within the genus Chalastinus; it differs in the non-tuberculate mesosternum and uncurved antennal joints, which appear, therefore, to be specific characters. Many examples were sent by Mr. Belt, and one of unusually large size by Mr. E. M. Janson.

\section{Anisocerus personatus.}

Oblongus, supra grosse sparsim punctatus, lateribus fuscus, in medio late albo-vittatus ; vittâ ely trorum bis dilatatâ, imprimis paulo ante medium, postea prope apicem, parte albâ fusco-punctatâ, punctis majoribus duobus ante medium prope suturam, alteris duobus magis approximatis ante apicem; corpore subtus nigro, cinereo-tomentoso; antennis $\delta^{t}$ corpore plus duplo longioribus, griseis, articulis apice nigris, articulo $3^{\circ}$ apice globoso et articulo ultimo brevi.

Long. 6-7 lin. ( $\delta^{\star}$, 우). 
The sides of the body above are blackish, varied with tawny-brown and dark punctures; the central ashy white streak, which is confined to a broad vitta on the head and thorax, forms on the elytra a figure resembling an elongate mask, of which the two small black dots on the anterior dilated portion represent the eyes, the larger spots behind near the suture the nose, and the dark apex of the elytra the mouth.

The insect is of a much more elongate figure than the other true Anisoceri, resembling in this respect much more the genus Caciomorpha of Thomson; but the dilated third joint, and the very much abbreviated eleventh joint of the antennæ, bring the species within the definition of Anisocerus.

\section{Lagocheirus rosaceus.}

$L$. araneiformi valde affinis; differt antennis, pedibus lineisque thoracis et elytrorum roseo-tomentosis; thorace valde punctato, maculis quatuor bene discretis nigris, lineisque irregularibus roseis; elyiris lineis numerosis roseis fusco-punctatis, pone medium maculas utrinque duas fuscas includentibus, ante has macula marginali majori semicirculari fusca, parte apicali lineis utrinque quinque longitudinalibus roseis.

Long. 9 lin. ( $\delta$, ㅇ) .

Many examples of this and the following species were sent.

\section{Lagocheirus $V$-album.}

L. araneiformi formâ similis ; multo obscurior, fuscus ; thorace utrinque vittâ abbreviatâ, a medio usque ad marginem posticum, fuscâ ; elytris obscure fuscis, vix variegatis, maculâ magnâ obscuriore laterali minus distinctâ, mox pone hanc liturâ albâ literam $\mathrm{v}$ vel $\mathrm{N}$ simulante; pedibus obscuris, tarsis pallidis, articulo unguiculari apice nigro excepto.

Long. $8 \frac{1}{2}$ lin. ( $。$, 우).

Amphionycha bifasciata.

Robusta, nigra, griseo subtiliter tomentosa; capite thorace paulo angustiori, fronte supra macula fulva; thorace supra fulvo vel roseo, maculis 3 nigris; elytris 
parallelis, apice flexuoso-truncatis et externe spinosis, fasciis duabus flavis vel roseis nigro-marginatis, fascia prima flexuosa, secunda obliqua ; antennis nigris, sparsim subtus ciliatis.

Long. $6-8$ lin. ( $\delta$, $q)$.

Many examples of both sexes.

Carneades, nov. gen. Colobotheinarum.

A Colobothea differt carina laterali elytrorum nulla vel indistincta, et articulo antennarum basali apice abrupte clavato.

\section{Carneades superba.}

Magna, crassa, elongata, antice posticeque attenuata, tomento ochraceo dense vestita; thorace supra maculis duabus, elytris fasciis quatuor, prima tertiaque macularibus, nigris, humeris antice curvatis, valde productis; antennis nigris, articulis basi griseis; pedibus nigris, nitidis, femoribus et tibiis posticis rufo-annulatis, annulis e tomento denso formatis, tarsis flavo-tomentosis, articulo unguiculari nigro.

\section{Long. 11 lin.-1 un.}

The design of the elytra in this fine insect consists of four transverse belts or rows of spots on a ground of dense yellowish tomentum; the first belt includes a black spot covering each shoulder, and two round spots near the suture; the second, a little before the middle, is entire except near the suture and oblique; the third consists of four equidistant spots ; and the fourth, near the apex, is entire excepting the sutural interruption. The prothorax beneath has on each side a narrow black stripe, and a small round spot above it. The middle of the breast is black.

\section{Carneades delicia.}

Minor, minus elongata, postice valde attenuata, cinereosubsericeo-tomentosa; signaturis elytrorum ut in $C$. superba, fascia secunda apud suturam haud interrupta et minus obliqua excepta; tarsis rufis, articulis $3^{\circ}$ et $4^{\circ}$ nigris.

Long. $6 \frac{1}{2}$ lin.

TRANS. ENT. SOC. 1869.-PART V. (DECEMBER.) 2 G 


\section{Jamesia multivittata.}

J. globiferce formâ similis; fusca, subnitida; capite angusto, fronte vittis duabus ochraceis ; thorace transversim grosse rugato, lateribus haud tuberculato, ochraceo sparsim tomentoso; elytris humeris angulatis, postice paulo attenuatis, basi tuberculis rotundis nigris sparsis, postice sparsim punctatis, basi et vittis, septem utrinque, in seriebus duabus transversis ordinatis, ochraceis; subtus ochraceo-tomentosa et nigro-punctata; antennis pedibusque nigro-piceis.

Long. $10 \frac{1}{2}$ lin.

Two examples.

\section{Deliathis nivea.}

Elongata, tomento densissimo niveo induta; capite supra vittulis quatuor, thorace vittis tribus, et elytris maculis numerosis, nigris, nitidis ; maculis elytrorum prope suturam et marginem condensis, disco multo rarioribus, apicibus mucronatis ; subtus medio corporis et ventris marginibus nigris nitidis; antennis pedibusque nigris, griseo tenuiter tomentosis.

Long. 1 un. 5 lin.

\section{LAMELLICORNIA.}

Allorrhina anomala.

Oblongo-quadrata, angusta, supra nigro-purpureo-velutina; thorace limbo angusto, postice abbreviato; elytris limbo laterali, maculis duabus transversis discoidalibus, et duabus marginalibus rotundatis prope apicem, flavis; mesosterno triangulari, crasso, convexo.

Mas : capite quadrato, lateribus utrinque cornu brevi elevato retrorsum spectante, thoraceque cornu anticomarginali brevi horizontali apice emarginato; tibiis anticis elongatis, linearibus, edentatis.

Long. 11 lin.; lat. 5 lin. $(\delta)$.

A remarkable species, agreeing with $A$. Lansbergii (Sallé) in the peculiar armature of the head and anterior margin of the thorax, in which both differ greatly from all other known species of Allorrhina, or Gymnetince. The peculiarity seems to arise from the development into 
horns of the lateral carinæ of the head, at the expense of the central horizontal horn, which is absent, as is also the horn at the edge of the clypeus.

One example only, received from Mr. Belt.

\section{Gymnetis ramulosa.}

Ad sectionem $G$. holosericece, etc. pertinens; processu mesosternali magno, crasso, deorsum curvato, et antice tuberculato; supra olivacea, velutina ; elytris limbis laterali et apicali angustis æqualibus, illo ramulos tenues duos vel tres emittente, uno pone medium in fasciam flexuosam prope ad suturam prolongato; abdomine $\delta$ nigro, nitido, 우 olivaceo, subopaco.

Long. 10 lin. ( $\delta$, 우).

A large number of specimens of this species were sent home by Mr. Belt. 


\section{$2 \mathrm{BHL}$ Biodiversity Heritage Library}

Bates, Henry Walter. 1869. "XXV. New species of Coleoptera from Chontales, Nicaragua." Transactions of the Entomological Society of London 1869, 383-389.

View This Item Online: https://www.biodiversitylibrary.org/item/51241

Permalink: https://www.biodiversitylibrary.org/partpdf/4776

\section{Holding Institution}

Smithsonian Libraries

\section{Sponsored by}

Smithsonian

\section{Copyright \& Reuse}

Copyright Status: Public domain. The BHL considers that this work is no longer under copyright protection.

This document was created from content at the Biodiversity Heritage Library, the world's largest open access digital library for biodiversity literature and archives. Visit BHL at https://www.biodiversitylibrary.org. 